\title{
Occurrence of Traumatic Dental Injury in Cases of Domestic Violence
}

\author{
Cléa Adas Saliba GARBIN \\ Ana Paula Dossi de Guimarães e QUEIROZ \\ Tânia Adas Saliba ROVIDA \\ Artênio José Isper GARBIN \\ UNESP - Univ Estadual Paulista, Araçatuba Dental School, Araçatuba, SP, Brazil
}

\begin{abstract}
The purpose of this study was to investigate the prevalence and types of traumatic dental injuries in situations of domestic violence. A coross-sectional study was conducted and data were collected from the police occurrence records to domestic physical aggression between 2001 and 2005. Of the 1,844 subjects who underwent medical evaluation, 15 had information pertaining to traumatic dental injuries. From the medical records, the forensic medical reports completed by the forensic medical experts who examined the victims after the aggression were reviewed and data of individuals with dental injuries (e.g., fractures, luxation and avulsion) were collected. In the selected sample, there was a predominance of individuals with injuries to the head and neck region (38.7\%), and the frequency of traumatic dental injuries among all injuries to the head and neck region was $2.0 \%$. The most frequently injured teeth were the maxillary incisors $(31.8 \%)$, followed by the mandibular incisors $(27.3 \%)$ and the maxillary canines $(9.1 \%)$. In $31.8 \%$ of the injured teeth, the forensic experts did not specify the nomenclature. Of the dental trauma cases, $59.1 \%$ were fractures, $27.2 \%$ were luxations and $13.7 \%$ were avulsions. In conclusion, domestic violence was an important etiologic factor of traumatic dental injury. The aggression in all cases occurred in the form of punches and slaps. Fracture was the most common type of traumatic dental injury, and the most frequently injured teeth were the incisors.
\end{abstract}

Key Words: forensic dentistry, violence, wounds and injuries, traumatic dental injury.

\section{INTRODUCTION}

Violence and accidents cause great damage to the physical and mental health of the most different populations, becoming a serious public health problem all over the world. Unfortunately, a large part of these cases occur in the domestic environment.

It is estimated that more than 2.5 million women are assaulted annually worldwide $(1,2)$. This number is probably much larger because physical abuse inflicted by family members within households is often hidden.

A number of studies related to primary health care of abused patients have shown that the head and neck are the most frequently injured areas as a consequence of physical aggression, resulting in fractures, contusions, burns and traumatic dental injuries $(3,4)$.

The risk factors for traumatic dental injury frequently involve aggressiveness and violent attitudes and must always be considered in the development of effective strategies for dental health preservation (5).
Listed as the third most common cause of traumatic dental injury, inter-relationship violence follows only domestic accidents and sporting activities $(6,7)$. However, at the time of diagnosis, the real cause of the injuries may remain occult. Most of the time, violent events and trauma are not accidental or simply a matter of fate because such trauma can be faced, prevented, and avoided.

In this sense, it is understood that the various social sectors must commit to hold information that may embarrass the preventive strategies. In the case of the police, these are generated from peer review. Whereas all cases of assaults recorded by the police sector are referred to the Institute of Forensic Medicine, this is an important tool for the design of the problem. Professionals who work on this site are responsible for examining the victim, determining the presence and types of injuries, and identifying the instrument that caused the injuries. This information is recorded and preserved, in a first moment, for police and legal purposes. However,

Correspondence: Profa. Dra. Ana Paula Dossi de Guimarães e Queiroz, Departamento de Odontologia Infantil e Social, Faculdade de Odontologia de Araçatuba, UNESP, Rua José Bonifácio, 1193, Vila Mendonça, 16015-050 Araçatuba, SP, Brasil. Tel: +55-18-3636-3249. e-mail: anadossi@foa.unesp.br 
if well-developed, it can help in the diagnosis of the situational question.

The treatment success and the implementation of measures to prevent the occurrence of trauma caused by aggression are dependent on epidemiologic information (8), which reinforces the importance of the studies like this one. The aim of this study was to investigate the prevalence and types of traumatic dental injuries in situations of domestic violence.

\section{MATERIAL AND METHODS}

In order to comply with all ethical requirements, the study protocol was reviewed and approved by the Ethics Committee of Araçatuba Dental School/UNESP, under the process \#2005-01861.

This is a documentary study, conducted from police records of incidents of physical violence. Data were collected at the Police Station for the Defense of Women of the city of Araçatuba, SP, Brazil. This policy station serves primarily women; however, it is also responsible for crimes involving children, adolescents and the elderly of both genders. The period of analysis was between January 2001 and December 2005. In this policy station 7,750 cases of several crimes were reported to the police. Among the 7,750 records, those involving domestic physical abuse corresponded to 1,844; among these, there were 15 cases of traumatic dental injury.

All cases of physical violence recorded in the police service are sent to the Institute of Forensic Medicine in which the victim is subjected to a physical examination and the facts of the assault are clarified. The examination is performed immediately after the record of the event and is conducted by a physician. After, the forensic medical expert prepares a report describing the specific form of the injuries and the instrument used. The forensic medical report is written and includes a detailed report of all the facts discovered by the medical expert. Upon completion, the document is attached to the police records of the occurrence. To collect the desired information, i.e., age and gender of the victim, location of the injuries, type of dental injury and tooth involved, and type of instrument that caused the injuries, the researchers evaluated the records and the reports issued by the forensic medical experts who examined the examination on the victims. The form used to collect the data is represented in Figure 1.

The victims were evaluated for the presence of dental fractures, dislocations and avulsions. There were no radiographs because the peer review was restricted to the physical examination of the patients. Information was collected and tabulated and the data entered in the statistical software Epi Info, version 3.2, for Windows. During data collection, the authors had no access to the names of the perpetrators or the victims. The anonymity of the forensic medical experts who issued the reports was preserved. In compliance with ethical principles, the victims authorized disclosure of the data retrieved by the medical experts for scientific purposes.

\section{RESULTS}

Of the 7,750 police cases registered within the

\begin{tabular}{|c|c|c|c|c|c|c|c|c|c|c|c|c|c|c|c|c|}
\hline \multicolumn{17}{|c|}{ Data Collection Form } \\
\hline \multicolumn{17}{|c|}{$\begin{array}{l}\text { - Gender: M ( ) F ( ) } \\
\text { - Age: } \\
\text { - Localization of lesions: ( ) Head and Neck ( ) Upper limbs （ ) Body （ ) Lower limbs } \\
\text { - Tooth involved and type of dental injury: }\end{array}$} \\
\hline Tooth & 18 & 17 & 16 & 15 & 14 & 13 & 12 & 11 & 21 & 22 & 23 & 24 & 25 & 26 & 27 & 28 \\
\hline \multicolumn{17}{|l|}{ Injury } \\
\hline Tooth & 48 & 47 & 46 & 45 & 44 & 43 & 42 & 41 & 31 & 32 & 33 & 34 & 35 & 36 & 37 & 38 \\
\hline Injury & & & & & & & & & & & & & & & & \\
\hline
\end{tabular}

Figure 1. Form used to collect the data. Araçatuba, São Paulo State, Brazil, 2010. 
study period, 1,844 were related to domestic physical abuse and were within the study scope. Of the 1,844 medical records analyzed, $1158(62.8 \%)$ had a forensic medical report.

The head and neck region was the most affected area, as shown in Table 1 (1,091 injuries [38.7\%]). The frequency of traumatic dental injuries caused by domestic violence among all injuries to the head and neck region was $2.0 \%$ (22 injuries).

Of the 1,844 cases of domestic violence, 15 forensic medical reports had information pertaining to traumatic dental injury, with 22 injured teeth. The most frequently injured teeth were the maxillary incisors ( 7 teeth [31.8\%]), followed by the mandibular incisors (6 teeth [27.3\%]), and the maxillary canines (2 teeth [9.1\%]). The specialists did not specify the nomenclature for 7 teeth (31.8\%). According to results, 59.1\% (13 teeth) of the teeth were fractured, $27.2 \%$ (6 teeth) had luxations, and $13.7 \%$ ( 3 teeth) had avulsions as a result of domestic violence.

The mean age of victims was 26.5 years, with a range between 4 and 39 years. The majority of victims were women (93.3\%). According to Table 2, victims in the 31-40-year-old age group had a greater variety of injuries.

In all cases $(100.0 \%)$ of traumatic dental injury, the aggression was inflicted by use of force only, i.e., without the use of weapons or other objects.

\section{DISCUSSION}

The investigation of the occurrence of traumatic dental injuries and data that emphasize its importance indicate their distribution, type and etiological factors is mandatory to elaborate preventive strategies and efficient treatment plans that can minimize their impacts.

Table 1. Distribution of characteristics of the 1,158 medical records related to domestic violence, based on lesion localization. Araçatuba, SP, 2010.

\begin{tabular}{lc}
\hline Localization of injuries* & $\mathrm{n}(\%)$ \\
\hline Head and meck region & $1,091(38.7)$ \\
Upper limbs & $933(33.1)$ \\
Body & $453(16.1)$ \\
Lower limbs & $342(12.1)$ \\
Total & $2,819(100.0)$ \\
\hline
\end{tabular}

*The victims could present injuries in one or more areas.
It seems clear that not only health care facilities and emergency services are responsible for the proper description and maintenance of epidemiologic information, but also all services that deal with the traumatized patient, such as Institutes of Forensic Medicine. Our results could not be compared objectively with findings of previous investigations because the literature is scarce on this subject, which emphasizes the importance of the present study in spite of its limitations.

The site for data collection and quality of information are factors that can provide more precise knowledge of the situation of violence and become more relevant to the actions of health, as it reflects the specificity of the target audience (9).

The lack of forensic medical reports in some cases of domestic violence can be due to a number of reasons, including the victim not attending to the Institute of Forensic Medicine. The distance between the police station and the Institute of Forensic Medicine could explain victim's non-attendance for forensic examination.

The face is usually one of the most affected regions in situations of violence and the treatment of the resulting injuries is a major public health problem. The predominance of injuries to the face found in this study is in accordance with the findings of previous studies $(3,4,10,11)$. The aggressor's preference for the face of the victim can be associated with the symbolic nature of humiliation that this kind of violence represents. When women are attacked, face aggression is associated with the aggressor's intention of damaging a socially appraised attribute: a woman's beauty. The head is the most exposed and accessible body area, and is considered the better representation of the individual (12).

Regarding traumatic dental injury, the victims were predominantly young women. However, it is possible to notice the existence of children and teenagers

Table 2. Distribution of traumatic dental injuries according to the age of victims. Araçatuba, SP, Brazil, 2010.

\begin{tabular}{lccccccccc}
\hline \multirow{2}{*}{$\begin{array}{l}\text { Age group } \\
\text { (years) }\end{array}$} & \multicolumn{2}{c}{ Avulsion } & & \multicolumn{2}{c}{ Fracture } & & \multicolumn{2}{c}{ Luxation } \\
\cline { 2 - 3 } \cline { 8 - 9 } \cline { 8 - 9 } & $\mathrm{n}$ & $\%$ & & $\mathrm{n}$ & $\%$ & & $\mathrm{n}$ & $\%$ \\
\hline $0-10$ & 1 & 25.0 & & 0 & 0 & & 0 & 0 \\
$11-19$ & 0 & 0 & & 2 & 15.4 & & 0 & 0 \\
$20-30$ & 0 & 0 & & 7 & 53.8 & & 3 & 50.0 \\
$31-40$ & 2 & 75.0 & & 4 & 30.8 & & 3 & 50.0 \\
Total & 3 & 100.0 & & 13 & 100.0 & & 6 & 100.0 \\
\hline
\end{tabular}


in this sample, confirming the occurrence of traumatic dental injury as an indicative of domestic violence against this group (12-14). Children's abuse can also result in contusions, burns or laceration of the tongue, lips, oral mucosa, palate (hard and soft palate), alveolar gingiva and frenum, injuries to the facial bones, and mandibular fractures (14).

A previous study assessing the occurrence of trauma in students (15) pointed to violence as the second most common cause of injury and highlighted that as information is obtained from the children's parents, mistakes must be considered, once the parents would not confess the aggression against their own children.

Fracture was the most predominant type of dental injury in the present study, which corroborates the findings of other studies (16). Another study, however, found subluxation the most predominant type of dental trauma (17). Incisors were the most frequently injured teeth, as reported elsewhere $(5,13-15,18,19)$. Certainly the anatomic localization and personal factors, such as accentuated overbite and incompetent lips, can explain the predominance of injuries to incisors over other teeth. However, it is not possible to confirm this information because a number of reports did not specify the injured teeth in the present study.

The region of the injuries can direct or indirectly influence the victim's life, affecting their appearance and communication, and reinforcing the idea that dental trauma can cause functional, esthetic, psychological and social problems (5). When anterior teeth are injured, these consequences are even worse.

In the present study, all injuries were inflicted by the aggressor's hands as the aggression instrument. The injuries caused by punches and slaps have also been shown to be prevalent in another study (12). These findings can be due to the fact that, in the aggression impulse, as the aggressor does not have any object in his/her hand, he/she attacks in the most probable way, using his/her hands as a weapon.

The occurrence of traumatic dental injury observed in the present study is in accordance with the findings of similar studies $(17,20)$. However, the quality of available data may represent an obstacle to the real knowledge of the situation. It is worth emphasizing, that some forensic medical reports did not specify the injured teeth, while other reports did not mention any injury to the teeth, even when it was reported by the victim, which suggests a negligent exam. This fact highlights the importance of having a forensic dentist as part of the team acting at the Institute of Forensic Medicine in the assistance to victims of physical abuse.

The forensic medical documentation is of major importance for the elucidation of judicial problems. The appropriate description of forensic medical injuries is essential not only for the applicability of opportune sanctions to each crime, but also for the good process of justice. Preservation of information is mandatory for planning actions that can prevent this kind of occurrence, it can add important data to those collected at health care services.

Based on the findings of the present study, it may be concluded that domestic violence was an important etiologic factor of traumatic dental injury. Aggression in all cases was inflicted by the aggressor's hands, without any object or instrument. Fracture was the most common type of traumatic dental injury, and the most frequently injured teeth were the incisors.

\section{RESUMO}

O objetivo deste estudo foi analisar a prevalência e os tipos de trauma dentário nas situações de violência doméstica. Trata-se de estudo transversal realizado a partir dos dados coletados nos registros de ocorrências policiais que se referiam a agressões domésticas físicas, em Araçatuba, SP, Brasil, entre 2001 e 2005. Do total de 1.844 prontuários, 15 continham informações sobre lesões dentárias. Foram analisados os laudos médico-legais emitidos pelos peritos e avaliadas todas as lesões referentes a trauma dentário, como fraturas, luxações e avulsões. Predominaram lesões em cabeça e pescoço (38,7\%). A freqüência dos casos de trauma dentário entre todas as lesões de cabeça e pescoço foi de $2.0 \%$. Dentre os dentes identificados, os mais acometidos foram os incisivos superiores $(31,8 \%)$, seguidos pelos incisivos inferiores $(27,3 \%)$, e os caninos superiores $(9,1 \%)$. Dentre os dentes traumatizados, $31,8 \%$ não tiveram a nomenclatura especificada pelos peritos, $59,1 \%$ sofreram fratura, $27,2 \%$ sofreram luxação e $13,7 \%$ sofreram avulsão. Pode-se concluir que a violência doméstica constituiu um importante fator etiológico de trauma dentário. As agressões, em todos os casos, ocorreram por socos e tapas. As lesões dentárias mais comuns foram fraturas, e os dentes mais acometidos, dentre os identificados, foram os incisivos.

\section{REFERENCES}

1. Stevenson TR, Goodall EA, Moore CBT. A retrospective audit of the extent and nature of domestic violence cases identified over a three year period in the two district command units of the police service of Northern Ireland. J Forensic and Legal Med 2008; 15:430-436.

2. Zeitler DL. The abused female oral and maxillofacial surgery patient: treatment approaches for identification and management. Oral Maxillofac Surg Clin North Am 2007;19:259-265.

3. Bithe Sr, Mahindra U, Halli R, Kini Y. Incidence and pattern of mandibular fractures in rural population: a review of 324 patients at a tertiary hospital in Loni, Maharashtra, India. Dent Traumatol 
2008;24:468-470.

4. Dossi AP, Saliba O, Garbin CAS, Garbin AJI. Epidemiological profile of domestic violence: complaints of aggression filed in a city in São Paulo State, Brazil, from 2001 to 2005. Reports in Public Health 2008;24:1939-1352.

5. Soriano EP, Caldas Jr AF, Carvalho MVD, Amorim Filho HA. Occurrence and risk factors related to traumatic dental injuries in Brazilian schoolchildren. Dent Traumatol 2007;23:232-240.

6. Gassner R, Tuli T, Hächl O, Rudisch A, Ulmer H. Craniomaxillofacial trauma: a 10 year review of 9543 cases with 21067 injuries. J Cranio-Maxillof Surg 2003;31:51-61.

7. Gerber B, Ahmad N, Parmar S. Trends in maxillofacial injuries in woman, 2000-2004. Br J Oral Maxillofac Surg 2009;47:374-377.

8. Mouzakes J, Koltai PJ, Kuhar S, Bernstein DS, Wing P, Salsberg E. The impact of airbags and seat belts on the incidence and severity of maxillofacial injuries in automobile accidents in New York State. Arch Otolaryngol - Head Neck Surg 2001;127:1189-1193.

9. Rezende EJC, Araújo TM, Moraes MAS, Santana JSS, Raicchi R. Mouth-dental injuries in women violence victims: a pilot study of registered cases in the Legal Medical Institute of Belo Horizonte, MG. Rev Bras Epidemiol 2007;10:202-214.

10. Bakardjiev A, Pechalova P. Maxillofacial fractures in Southern Bulgaria - a retrospective study of 1706 cases. J Cranio-Maxillof Surg 2007;35:147-150.

11. Garbin CAS, Garbin AJI, Dossi AP, Dossi MO. Domestic violence: an analysis of injuries in female victims. Reports in Public Health 2006;22:2567-2573.

12. Cairns AM, Mok JYQ, Welbury RR. Injuries to the head, face, mouth and neck in physically abused children in a community setting. Int J Pediatr Dent 2005;15:310-318.
13. Kahabuka FK, Mugonzibwa EA. Risk factors for injuries to maxillary permanent incisors and upper lip among schoolchildren in Dares Salaam, Tanzania. Int J Paediatr Dent 2009;19:148-154.

14. Kellogg N. Oral and dental aspects of child abuse and neglect. Pediatrics 2005;116:1565-1568.

15. Sgan-Cohen HD, Yassin H, Livny A. Traumatic dental injury among 5th and 6th grade Arab schoolchildren in Eastern Jerusalem. Dent Traumatol 2008;24:458-461.

16. Guedes OA, Alencar AHG, Lopes LG, Pécora JD, Estrela C. A retrospective study of traumatic dental injuries in a Brazilian dental urgency service. Braz Dent J 2010;21:153-157.

17. Gassner R, Bösch R, Tuli T, Emshoff R. Occurrence of traumatic dental injury in 6000 patients with facial injuries implications for prevention. Oral Surg Oral Med Oral Pathol Oral Radiol Endod 1999;87:27-33.

18. Baldava P, Anup N. Risk factors for traumatic dental injuries in an adolescent male population in India. J Contemp Dent Pract 2007;8:35-42.

19. Mestrinho HD, Bezerra AC, Carvalho JC. Traumatic dental injuries in Brazilian pre-school children. Braz Dent J 1998;9:101104.

20. Eyuboglu O, Yilmaz Y, Zehir C, Sahin H. A 6-year investigation into types of traumatic dental injury treated in a pediatric dentistry clinic in Eastern Anatolia Region, Turkey. Dent Traumatol 2008;15

Received February 25, 2011

Accepted December 13, 2011 